\title{
Hygiene Mental pada Konsep Perencanaan Klinik dan Fasilitas Edukasi untuk Ibu dan Anak di Surabaya
}

\author{
Merin Eka Shabrina ${ }^{1}$, Failasuf Herman ${ }^{2}$ \\ ${ }^{1}$ Jurusan Arsitektur, Fakultas Teknik Sipil dan Perencanaan, Institut Teknologi Adhi Tama Surabaya \\ ${ }^{2}$ Jurusan Arsitektur, Fakultas Teknik Sipil dan Perencanaan, Institut Teknologi Adhi Tama Surabaya \\ Email: ${ }^{1} \underline{\text { merineka@gmail.com }}$
}

\begin{abstract}
Planning and designing clinics and educational facilities for mothers and children are objects that aim as a means of health and education services for the care of pregnant women to childbirth and children in their growth based on restoring the conditions experienced. It is very possible to influence the mental condition of pregnant women and childbirth. Mental condition of children can also be disrupted if the parenting provided by parents is less able to encourage or support aspects of growing so as to cause the child to experience growth retardation and will affect when children go into adolescence to adulthood.

To create a healthy environment both psychologically and physically, the selection of architectural themes with environmental insight is able to help create an environment that not only configurated the relationship with the surrounding environment but also setting the environment within the site which creates a healthy environment for observers, users of all residents but in specifically for patients namely mother and child. This design also uses a mental hygiene based approach to the context of the environment (healing environtment) as a means of healing and recovery.
\end{abstract}

Keywords: Mother and Child Clinic, Educational Facilities, Mental Hygiene

\begin{abstract}
Abstrak.Perencanaan dan perancangan klinik dan fasilitas edukasi untuk ibu dan anak merupakan objek yang bertujuan sebagai sarana pelayanan kesehatan dan edukasi untuk ibu hamil hingga melahirkan dan anak dalam masa perkembangannya yang berbasis memulihkan kondisi yang dialami. Hal ini dapat mempengaruhi kondisi mental dari ibu hamil dan pasca melahirkan. Kondisi mental anak juga bisa terganggu jika pola asuh yang di berikan oleh orang tua kurang mampu mendorong atau mendukung aspek perkembangan sehingga menyebabkan anak mengalami keterlambatan pertumbuhan dan akan berpengaruh ketika anak beranjak remaja hingga dewasa.

Untuk mewujudkan lingkungan yang sehat baik secara psikis dan fisik pemilihan tema arsitektur berwawasan lingkungan diharapkan mampu membantu menciptakan lingkungan yang tidak hanya mengatur adanya keterkaitan bangunan dengan lingkungan sekitar namun juga mengatur lingkungan dalam tapak guna menciptakan lingkungan dengan suasana yang sehat baik bagi pengamat, pengguna dan semua penghuni, khususnya untuk pasien yaitu ibu dan anak. Perancangan ini juga menggunakan pendekatan berbasis higiene mental dengan konteks lingkungan (healing environtment) sebagai sarana penyembuhan dan pemulihan.
\end{abstract}

Kata Kunci: Klinik Ibu dan Anak, Fasilitas Edukasi, Higiene Mental

\section{Pendahuluan}

Pendidikan keluarga adalah pendidikan yang pertama dan utama bagi anak. Salah satu aspek terbesar yang mempengaruhi baik buruk tumbuh kembang anak pada saat ini adalah peran lingkungan dan pengaruh teknologi digital (internet). Lingkungan yang dimaksud adalah keluarga. Dalam lingkup keluarga, peran orang tua, kerabat terdekat dan lingkungan tempat tinggal atau tumbuh kembang anak mampu memberi pengaruh baik atau buruk akibat kebiasaan anak meniru orang lain. Pada sisi yang lain, pengaruh teknologi digital (internet) juga bisa memberikan dampak positif ataupun negatif yang mempengaruhi pola pikir, sikap dan perilaku orang tua dalam mendidik seorang anak. Fasilitas ini direncanakan dan dirancang guna memberikan layanan kesehatan dan edukasi yang benar bagi ibu dan anak. Dalam konteks yang lain terkait kondisi seorang ibu khususnya dalam masa kehamilan hingga pasca melahirkan dimana adanya stres saat hamil merupakan kondisi normal yang banyak dialami oleh para ibu yang tentunya perlu diberikan layanan pendampingan.

Berbagai macam permasalahan bisa mempengaruhi kesehatan mental yang berasal dari konflik pribadi atau permasalahan lain. Gangguan kesehatan mental juga bisa menghampiri siapa saja, baik 
seorang anak maupun orang dewasa sekalipun. Berdasarkan kebutuhan tersebut, maka diperlukan sebuah sarana yang mampu memfasilitasi pasien dalam kondisi khusus tersebut agar dapat kembali sehat baik secara mental maupun fisik.

\subsection{Tinjauan Pustaka}

Tema yang digunakan adalah Arsitektur Berwawasan Lingkungan yang berperan sebagai kontrol lingkungan yang diciptakan pada lingkungan objek yang akan di rancang, yakni adanya hubungan atau kesinambungan yang tercipta dengan melihat potensi di sekitar lingkungan objek. Dengan adanya fasilitas sarana kesehatan dan perawatan ini diharapkan mampu menunjang kebutuhan masyarakat disekitarnya. Selain itu kesinambungan juga tercipta melalui pengolahan desain yang akan mempengaruhi lingkungan sekitar objek rancangan. Tema Arsitektur Berwawasan Lingkungan nantinya akan didukung dengan konsep makro berupa hygiene mental sehingga didapatkan sebuah konsep perancangan yang tidak hanya mewadahi fasilitas pelayanan kesehatan secara medis, namun juga berperan sebagai penunjang kesehatan secara psikis atau mental.

Berdasarkan beberapa uraian diatas, maka pengertian dari judul "Perancangan dan Perencanaan Klinik dan Fasilitas Edukasi Berbasis Higiene Mental di Surabaya" adalah sebuah proses merencanakan dan merancang bangunan dengan fungsi pelayanan kesehatan, edukasi juga terdapat fasilitas penunjang seperti perawatan untuk ibu dan anak serta fasilitas pelengkap lainnya yang dikemas secara terpadu.

\subsection{Metode Penelitian}

Kajian dalam penelitian desain ini menggunakan metode diskriptif dan analisa studi preseden yang bertujuan memberikan wawasan terkait objek yang akan di rancang. Pengumpulan data dilakukan melalui metode survey, wawancara, pengamatan, dan studi kasus literatur maupun lapangan.

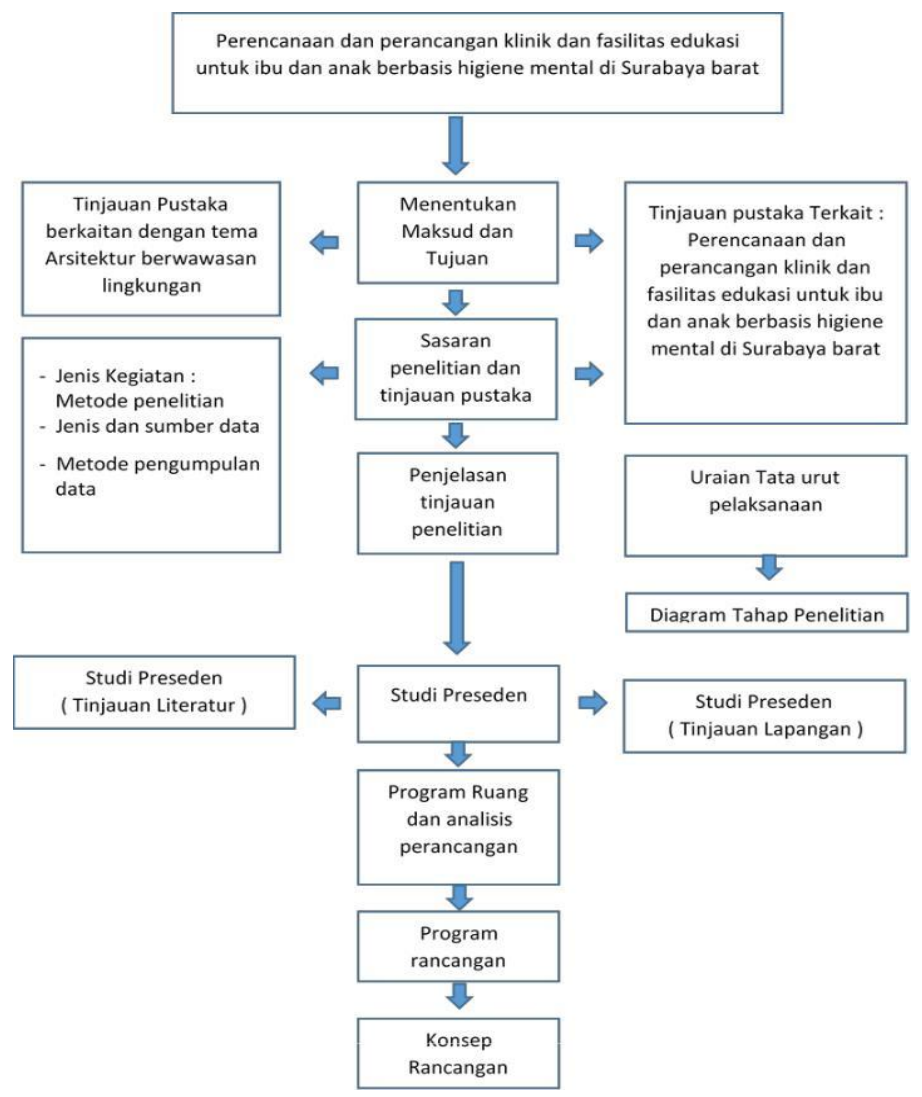

Gambar 1. Diagram alur pikir desain

\section{Pembahasan}


Berdasarkan pendekatan Arsitektur Berwawasan Lingkungan maka skenario konsep Perencanaan dan Perancangan Klinik dan Fasilitas Edukasi Untuk Ibu dan Anak Berbasis Higiene Mental di Surabaya dapat dijabarkan sebagaimana uraian berikut.

\subsection{Konsep Makro}

Pada perancangan konsep makro menggunakan pendekatan hygiene mental yang berorientasi mewujudkan/ mengembalikan kondisi psikologi yang sehat kategori pasien dalam kondisi khusus di wujudkan melalui desain Klinik dan fasilitas edukasi sebagai pendukung untuk menstimulasi penyembuhan dan pemulihan. Melalui penekanan komponen alam, psikologis, fisik, indra, dan komponen perilaku dari perawatan kesehatan yang memungkinkan kapasitas tubuh untuk menyembuhkan dirinya sendiri.

\subsection{Konsep Mikro Healing Environtment pada Tata Lahan}

Pada konsep mikro tatanan lahan menggunakan konsep Healing Environtment yakni menciptakan tatanan lahan yang mendukung fungsi bangunan dan menampilkan citra bangunan dan lingkungan yang baik.
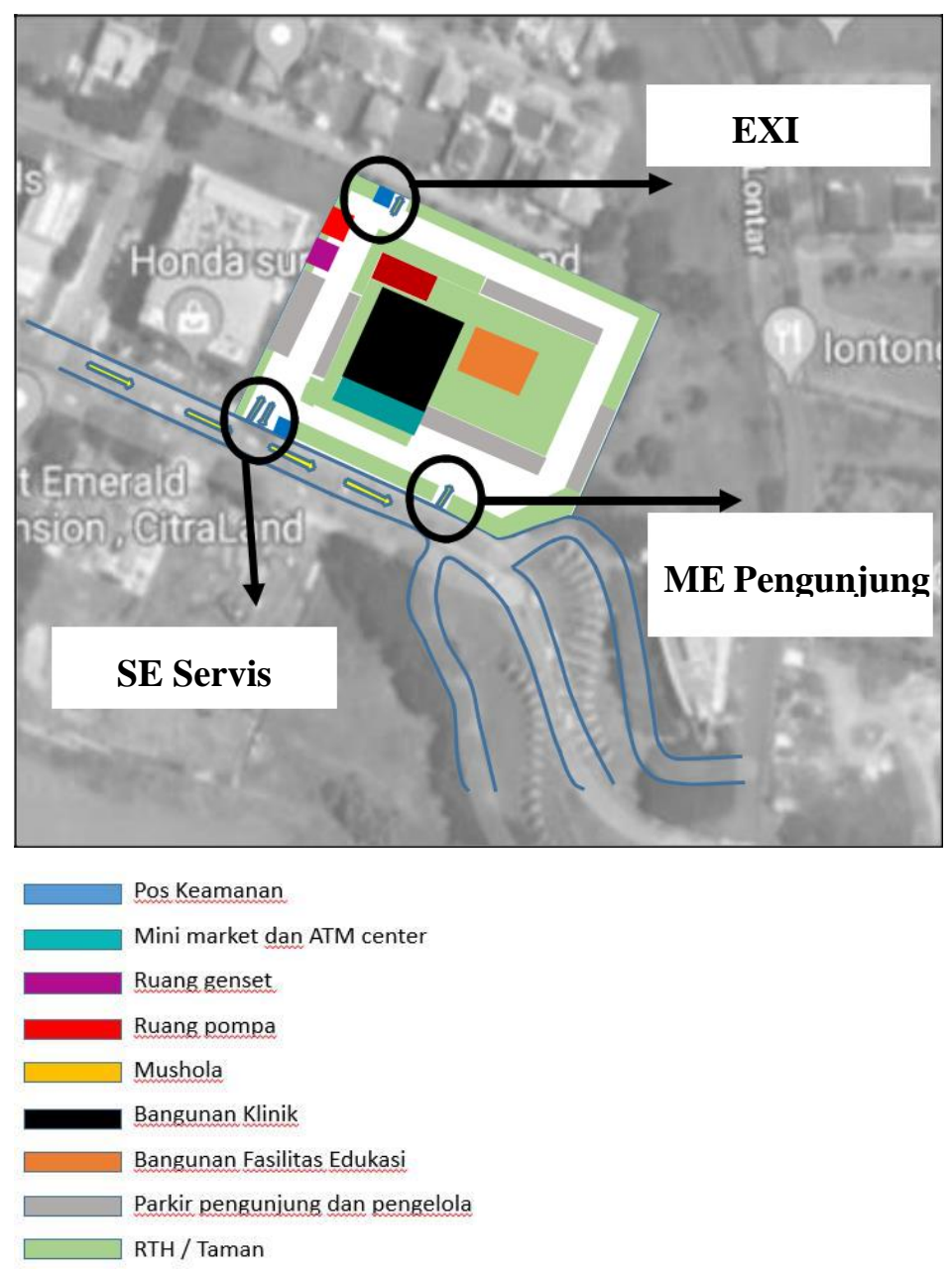

Gambar 2. Penataan lahan

Selain terkait fungsi dan citra, lingkungan binaan ini di harapkan akan mempengaruhi psikologi pasien untuk beradaptasi dengan proses pemulihan perawatan kesehatan yang memungkinkan kapasitas tubuh untuk menyembuhkan dirinya sendiri.

\subsection{Konsep Mikro User Friendly pada Bentuk}


Pada dasarnya ide bentuk yang diadopsi adalah dari bentuk susunan lego, dengan pengolahan desain yang dinamis, dari segi komposisi bentuk geometri maupun warna.

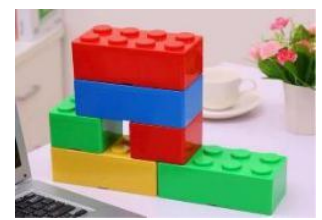

Gambar 3. Ide bentuk penyusunan lego
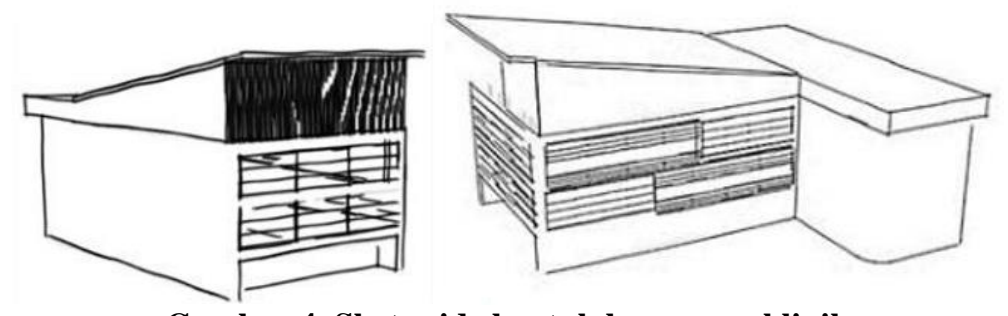

Gambar 4. Sketsa ide bentuk bangunan klinik
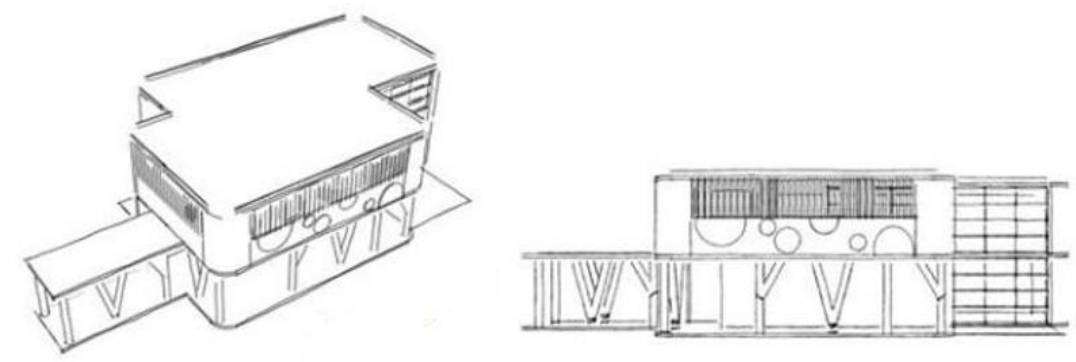

Gambar 5. Sketsa ide bentuk bangunan edukasi

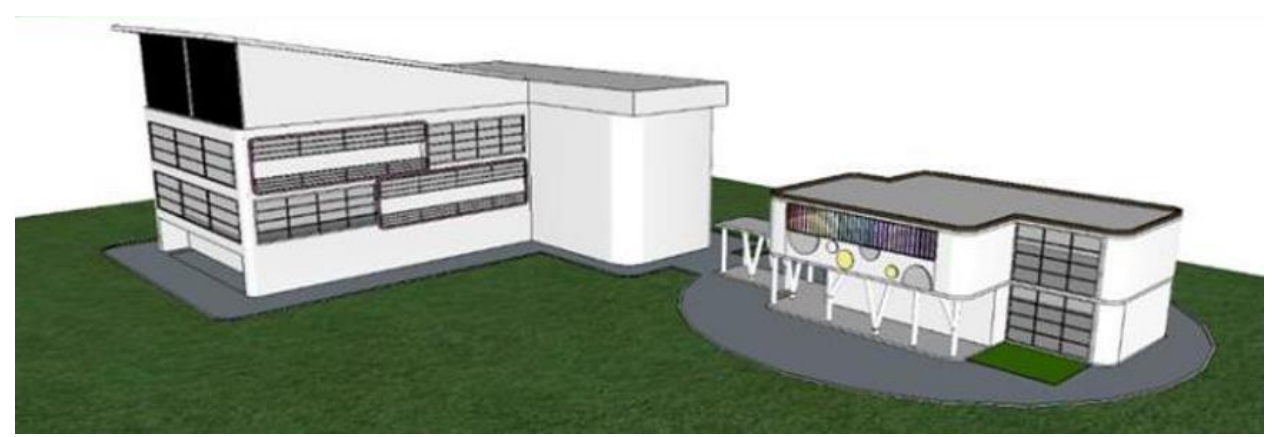

Gambar 6. Transformasi bentuk bangunan klinik dan bangunan edukasi

Pada konsep mikro bentuk pemilihan konsep user friendly diharapkan mampu menciptakan desain bentuk yang ramah untuk semua pengguna namun di khususkan terhadap pengguna utama yaitu ibu dan anak. Ditinjau dari pemilihan bentuk geometri, pemilihan warna yang berdampak kepada psikologi pengamat.

\subsection{Konsep Mikro Responsive pada Ruang}

Pada konsep mikro ruang Responsive diharapkan mampu menciptakan ruang yang sehat, melalui elemen pembentuk dan aksesoris ruang yang dapat memenuhi kebutuhan secara fisik dan psikis pengguna sehingga tercipta suasana ruang yang nyaman, aman dan menyenangkan yang akan membantu dalam proses pemulihan pasien. 

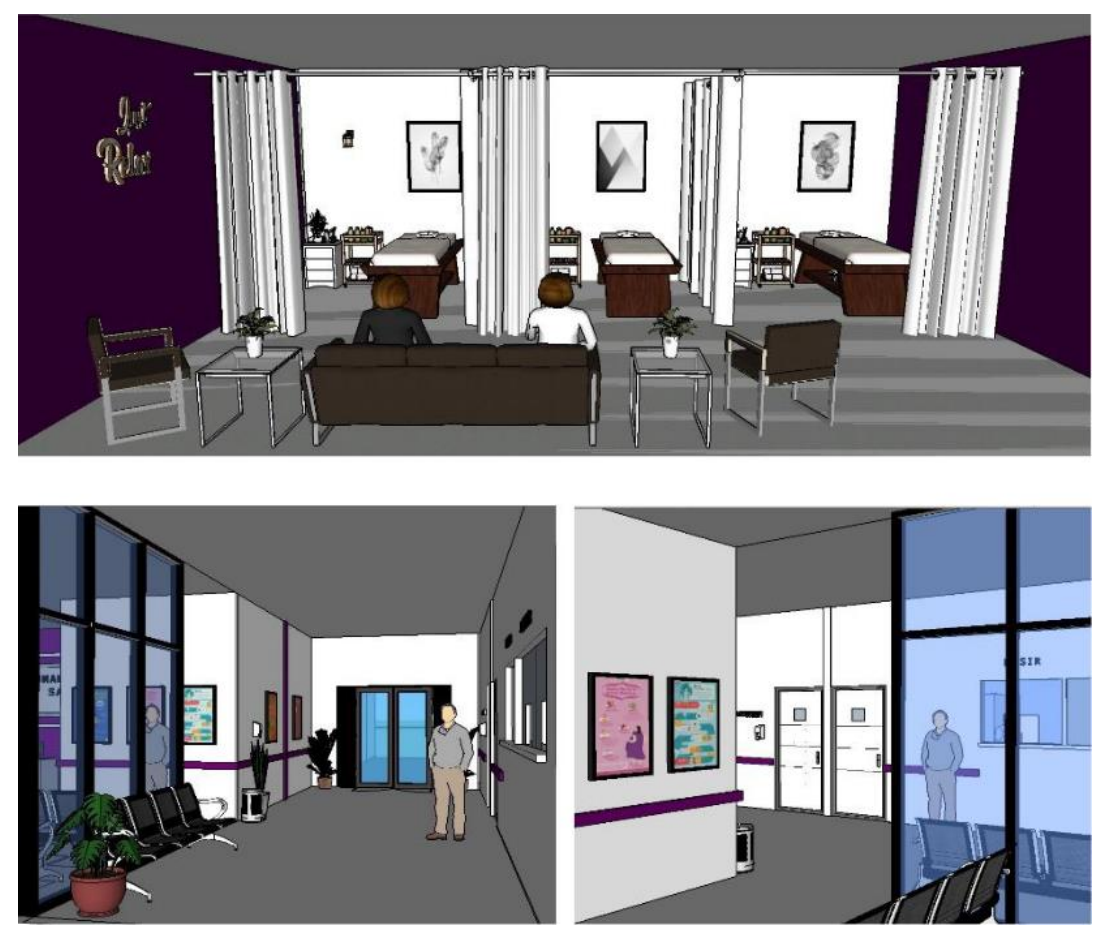

Gambar 5. Sketsa ide ruang dalam

\section{Kesimpulan}

Hygiene Mental pada Konsep Perencanaan Klinik dan Fasilitas Edukasi untuk Ibu dan Anak di Surabaya ini dapat menjadi wadah untuk fasilitas kesehatan serta pelayanan edukasi untuk ibu dalam kategori hamil hingga melahirkan dan juga anak usia dini. Adanya fasilitas ini diharapkan dapat menurunkan resiko terjadinya gangguan kesehatan dan juga mental yang dialami oleh ibu hamil dan anak terkait dengan pola asuh, perkembangan dan pertumbuhan anak.

\section{Referensi}

"Hygiene Mental". Diakses dari: https://kbbi.web.id/higiene

"Prinsip Pembangunan Berwawasan Lingkungan". Diakses dari: http://eprints.umm.ac.id

Mentreri Kesehatan Republik Indonesia. 2014. "Peraturan Menteri Kesehatan No. 9 Tahun 2014 tentang Klinik”. Berita Negara Republik Indonesia Tahun 2014 No. 232. Jakarta: Menkumham. Diakses dari: https://peraturan.bpk.go.id/Home/Details/117304/permenkes-no-9-tahun-2014 
